\title{
GROWING \\ Longleaf Pine \\ SEEDLINGS IN CONTAINERS
}

\section{Abst ract}

We provide basic guidelines for nursery production of longleaf pine (Pinus palustris P. M ill. [Pinaceae]) seedlings in containers. The best seedlings are spring sown, grown outdoors in full sun in cavities with a $100-\mathrm{ml}\left(6 \mathrm{in}^{3}\right)$ volume, $11-\mathrm{cm}(4.5$ in) depth, and a density around 535 seedlings per $\mathrm{m}^{2}\left(50 / \mathrm{ft}^{2}\right)$. A 1:1 peat moss:vermiculite medium adjusted to $\mathrm{pH} 4.5$ to 5.5 and amended with control-release or soluble fertilizers works well. Planting of container stock generally improves reforestation success because survival is good, the planting season can be extended, and therefore, restoration of the longleaf pine ecosystem is enhanced. KEYWORDS: Pinus palustris, nurseries, seedling establishment, seed quality

NOMEN CLATURE: ITIS (1998)
$\mathrm{O}$ $f$ all the southern pines, many consider longleaf pine (Pinus palustris P. M ill. [Pinaceae]) the most valuable in terms of woodproduct quality, aesthetics, and resistance to fire, insects, and disease. Before European settlement, about 36 million ha (90 million ac) of longleaf pine ecosystem extended from east Texas through the lower C oastal Plain to Virginia. H eavily harvested in the late 1800s and early 1900s, few longleaf stands survived (Wahlenburg 1946). Since few seed trees survived these harvests, much of the area was converted to other species or abandoned to grassland. Today, natural regeneration is only feasible on a small portion of the area in longleaf pine type.

W hy have we failed to regenerate more longleaf pine sites? Answers to this question are related to unique botanical characteristics of the species: 1) low and infrequent seed production; 2) a seedling "grass" stage characterized by delayed stem

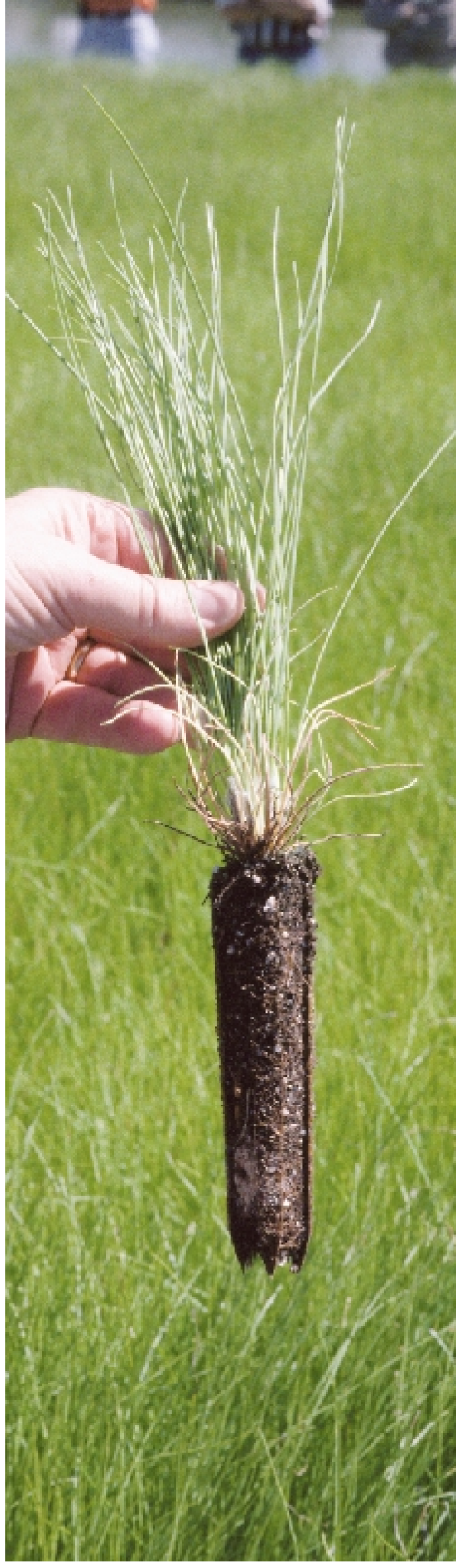

Figure 1 - A longleaf pine seedling growing in an outdoor growing area in Georgia. 
elongation; 3) poor storability of bareroot nursery stock resulting in low survival; and 4) seedling intolerance to shade conditions caused by competition.

Knowledge and technology to reestablish longleaf pine by planting bareroot seedlings have improved significantly in the last decade. Essential components of successful regeneration include: 1) wellprepared, competition-free sites; 2) healthy, top-quality, fresh planting stock; 3 ) meticulous seedling care structure (Figure 1). T hose grown in full sunlight are superior to those grown in shaded structures (Table 1). A $30 \%$ shade cloth over a simple framework will greatly reduce the hazard of hard rainfall washing seeds from containers during germination. Remove the cloth as soon as germination is complete. If crops are overwintered, polyethylene or other protective coverings may be needed to protect seedlings from strong desiccating winds and cold temperatures. Although shoots are cold

\section{TABLE 1}

\begin{tabular}{lcccc}
\hline \multicolumn{4}{c}{ M orphological characteristics of } \\
$\begin{array}{l}\text { Root collar } \\
\text { diameter } \\
(\mathbf{m m})\end{array}$ & $\begin{array}{c}\text { Shoot } \\
\text { weight } \\
(\mathbf{g})\end{array}$ & $\begin{array}{c}\text { Root } \\
\text { weight } \\
\mathbf{( g )}\end{array}$ & $\begin{array}{c}\text { Root to } \\
\text { shoot } \\
\text { ratio }\end{array}$ \\
\hline Treatments & 6.0 & 3.0 & 0.9 & 0.30 \\
\hline Full sun & 4.1 & 2.1 & 0.3 & 0.14 \\
Shade (30\%) & & & & \\
Source: Barnett (1989). & & &
\end{tabular}

from lifting to planting; 4) precision planting; and 5) proper postplanting care. Controlling these 5 elements is difficult, so planting success of bareroot stock still remains elusive.

We have demonstrated that under adverse planting conditions, container-grown seedlings survive and grow better than bareroot stock (Barnett and M CGilvray 1993; South and Barnett 1986). Improved survival and growth rates are generally attributed to intact root systems compared to root systems of bareroot plants that are severely damaged during lifting. Thus, container seedlings experience a significantly shorter period of transplant shock or adjustment. The purpose of our paper is to provide information to help nursery managers produce high quality longleaf pine container stock.

\section{Facilities}

There is little need for elaborate facilities to produce container stock in the South. Longleaf pine seedlings are typically grown without a tolerant, the root system is susceptible to cold damage below $-4{ }^{\circ} \mathrm{C}$ (25 ${ }^{\circ} \mathrm{F}$ ) (Tinus and others 1999).

An adequate watering system is essential and should supply an even distribution of water, fertilizer, and fungicides as prescribed (Landis and others 1989). A simple, stake-type system with sprinkler heads is usually sufficient.

\section{Containers}

An ideal container cavity for longleaf pine production should have a volume of about $100 \mathrm{ml}\left(6 \mathrm{in}^{3}\right)$, a minimum depth of $11 \mathrm{~cm}$ (4.5 in), and a density less than 535 seedlings per $\mathrm{m}^{2}\left(50 / \mathrm{ft}^{2}\right)$. Styroblocks, H IKO, and Ropak Multi-Pot containers are typically used in the South (Table 2). Smaller containers that improve economics can be used if cultural practices are carefully controlled. U se only one type and size of container within a growing area because cultural practices, especially irrigation, differ among areas and growth phases. If container types are mixed, each type should be kept under a separate watering system.

\section{M edia}

A 1:1 mix of sphagnum peat moss and \#2 grade horticultural vermiculite has been a consistently good product for growing seedlings. This mixture has physical and chemical properties resulting in good waterholding capacity, aeration, and cation exchange capacity. The quality of peat moss and vermiculite varies among sources. Peat moss should be screened to remove large sticks and vermiculite should be a coarse grade because fine grades of vermiculite reduce aeration and impede drainage. A portion of perlite (up to $30 \%$ ) should be added to improve drainage if heavy rainfall is typical at the nursery. D epending upon the scale of operation, nursery managers may purchase a commercial medium or custom blend it at the nursery. M edium $\mathrm{pH}$ should be adjusted, if necessary, to about 4.5 to 5.0 to restrict pathogen development. H owever, if water $\mathrm{pH}$ is 7.5 to 8.0, withhold compounds that raise $\mathrm{pH}$ of the medium.

TA B LE 2

Commonly used containers

for longleaf pine container production

\begin{tabular}{lrrrrrr} 
& \multicolumn{5}{c}{$\begin{array}{c}\text { Cavity characteristics } \\
\text { Volume-Depth-Density }\end{array}$} \\
\cline { 2 - 7 } Container & $\boldsymbol{m l}$ & \multicolumn{1}{c}{$\mathbf{c m}^{\mathbf{m}}$} & $\boldsymbol{m}^{\mathbf{2}}$ & $\mathbf{i n}^{\mathbf{3}}$ & $\boldsymbol{i n}$ & $\mathbf{f t}^{\mathbf{2}}$ \\
\hline RL Stubbies & 115 & 14 & 527 & 7 & 5.5 & 49 \\
Styroblock 6 & 103 & 9 & 527 & 6 & 6.0 & 49 \\
Styroblock 8 & 131 & 15 & 441 & 8 & 6.0 & 41 \\
Multipot 3/96 & 98 & 12 & 441 & 6 & 5.0 & 41 \\
Multipot 4/96 & 148 & 9 & 441 & 9 & 6.5 & 41 \\
Multipot 2/67 & 65 & 12 & 85 & 4 & 4.0 & 79 \\
HIKO V-93 & 93 & 9 & 527 & 6 & 3.5 & 49
\end{tabular}


$M$ any amendments can be incorporated into the medium during mixing, including a surfactant to improve the uniformity and rate of moisture distribution through the medium, an insecticide to reduce the magnitude of fungus gnat (Bradysia spp. [D iptera: Sciaridae]) infestations (Barnett and M cG ilvray 1997), ectomycorrhizae spores to improve mycorrhizal development on root systems, and controlled release nutrients to enhance seedling development in the nursery. Such amendments should not normally be added unless experience shows a need, but because longl eaf pine has little stem el ongation, most growers incorporate 8 to $9 \mathrm{mo}$, controlled release fertilizer (typically 0 smocote $18 \mathrm{~N}: 6 \mathrm{P}_{2} \mathrm{O}_{5}: 12 \mathrm{~K}_{2} \mathrm{O}$ at 2 to $3.5 \mathrm{~kg} / \mathrm{m}^{3}$ [6 to $10 \mathrm{lb} / \mathrm{yd}^{3}$ ] of medium) to reduce the frequency of soluble fertilizer applications during the growing period (Landis and others 1989). M ycorrhizae development is usually adequate from wind-borne spores and inoculation is not needed for typical reforestation sites. Incorporation of spores is justified only on very difficult sites or those outside the normal range of southern pines.

\section{Seeds}

U se high-quality seeds (viability $>80 \%$ is desired) to reduce costs of sowing multiple seeds and thinning to 1 seedling per cavity. 0 btaining high-quality longleaf pine seeds remains a problem. To achieve good seed quality, organizations involved in the collection and processing of longleaf seeds need to pay particular attention to cone maturity at collection and seed processing techniques (Barnett 1997). Seeds are large (about 2000/kg [4500/lb]), have thin seedcoats and a persistent wing, so they are subject to damage during processing. Since longleaf seeds commonly have significant populations of pathogenic fungi that result in seedling mortality, a fungicidal seed treatment is generally effective in reducing early seedling mortality. If seeds have low viability or vigor, soaking seeds for $1 \mathrm{~h}$ in $30 \%$ hydrogen peroxide or $10 \mathrm{~min}$ in a benomyl (Benlate) solution ( 5 $\mathrm{g} / \mathrm{l}$ [2 tbsp/gal]) reduces fungal infestation and improves germination (Barnett and others 1999).

\section{Cultural Practices}

The best growing schedule, both biologically and economically, is to sow seeds in spring ( $M$ arch to $M$ ay depending upon location), grow seedlings through the summer, harden them naturally in the fall, and outplant in late fall or early winter (Brissette and others 1991). The best seed sowing strategy is to sow 1 seed per cavity if high quality seeds are available. If viability ranges from $65 \%$ to $80 \%$ (typical for many longleaf pine seed lots), sow 2 seeds per cavity and then if 2 seedlings germinate, thin 1 seedling about the time the seedcoats shed. Regardless of sowing strategy, oversowing and thinning is preferred to transplanting germinants (Pawuk 1982) although a concern about oversowing is scarcity of available seeds.

The scale of operation determines whether seeds are sown by hand, simple templates, or more elaborate seeding machines. To facilitate germination, most growers cover seeds with a thin layer of medium, grit, or vermiculite, but no more than about $3 \mathrm{~mm}$ (0.125 in) deep. D eep covering slows germination and increases occurrence of damping-off and other disease problems (Barnett 1988).

Controlling temperature is critical during the germination phase because longleaf pine seeds, ecologically adapted to fall germination (Wahlenburg 1946), germinate better at cooler temperatures than
Figure 2 - Controlling planting depth is important for longleaf pine seedlings. Source: Barnett and MCGilvray (1997). other pines species. Therefore, day and night germination temperatures should be near $22^{\circ} \mathrm{C}\left(72^{\circ} \mathrm{F}\right)$ with a permissible range of 15 to $27^{\circ} \mathrm{C}(60$ to $80^{\circ} \mathrm{F}$ ). Plant seeds in April or early $M$ ay when temperatures are usually near this range. Top growth is minimal, but root growth is extensive. Thinning or transplanting, if done, should be done during the first few weeks after germination.

Water management during the germination phase is critical. Water frequently but lightly to facilitate 
germination. As seedlings develop, watering should become heavier and less frequent. 0 verwatering early in the growing period is a common problem and may lower germination and promote disease. Water management is a critical aspect of nursery culture and is one that takes time to learn. An easy way to determine when to irrigate is by using container weights. When a container weighs some percentage of the weight when medium is at field capacity, irrigation is needed (see Landis and others 1989). The percentage changes during the growing season, but is usually $80 \%$ to $85 \%$ early in the season and $70 \%$ to $75 \%$ during hardening.

Fungicide applications to longleaf pine seedlings should begin as soon as feasible to reduce damping-off and inhibit pathogenic fungi development. Fusarium typically causes seedling mortality and fungicides labeled for its control are recommended. If controlled release fertilizers are not used, fertilization of seedlings should begin within 2 wk of germination with the first fungicide application. Water soluble fertilizers like Peters Peat-Lite Special $\left(15 \mathrm{~N}: 16 \mathrm{P}_{2} \mathrm{O}_{5}: 17 \mathrm{~K}_{2} \mathrm{O}\right)$ are effective with a peat moss:vermiculite mix.

Seedlings must be carefully observed for pest and weed problems. Insect problems may include cutworms, fungus gnats, and ants. Weed seeds may be incorporated in the peat moss, wind-borne, or spread through the water system if the water source is a pond or river. If weeds spread throughout the crop, a herbicide may be applied. Experience has shown that oxyfluorfen (G oal 1.6E) controls a broad spectrum of grasses and broadleaf weeds in conifer seedbeds and container stock. Since the seedlings are usually young when weeds develop, use about one-fourth the recommended rate of oxyfluorfen to ensure no damage occurs to the crop. If a weed problem is anticipat- ed, apply a pre-germination application at the recommended rate.

Since stem elongation is delayed, rapid growth for this species is exhibited primarily by needle growth. Initiation and length of the exponential growth phase is determined by both needle and stem caliper growth. Frequency of fertilization depends upon whether controlled release nutrients were incorporated into the mix and seedling development rate. H eavy fertilization schedules promote root collar growth, but may require needle clipping to prevent lodging of extra-long needles that may reach 30 to $35 \mathrm{~cm}$ (12 to 14 in) in length. Growers of large crops tend to reduce fertilization amount to limit needle length. If needles begin to lie over neighboring seedlings, clipping may be needed to prevent problems with non-uniform growth and pathogen development. Carefully clip only enough of the needles to reduce the problem - needles should 
not be clipped $\leq 15 \mathrm{~cm}$ (6 in) in length because excessive clipping reduces growth (Barnett and M cGilvray 1997).

Large seedlings toward the end of the growing season will require frequent watering to meet transpirational losses. H owever, the medium should be allowed to dry near the wilting point between applications to enhance hardening, root, and mycorrhizae development. Few, if any, nutrients should be applied during this period.

\section{Extraction, Storage, and PI anting}

Growers may extract seedlings from containers at the nursery or ship the containers with seedlings and extract them in the field. Extracting seedlings at the nursery reduces the bulk for shipping and limits loss and damage of costly containers that are reused to reduce production costs. Before extraction the root plug should be watered to field capacity. During extraction, cull poorly developed seedlings. Q uality seedlings should have a root plug that holds together during extraction, have abundant secondary needle development, and a root collar diameter of about 7 to $9 \mathrm{~mm}$ (0.28 to 0.35 in). Place seedlings in cardboard boxes for storage and shipment. Properly hardened, container longleaf seedlings can be extracted, boxed and stored under refrigeration at 1 to $3^{\circ} \mathrm{C}$ (34 to $38{ }^{\circ} \mathrm{F}$ ) for several weeks.

D espite their bulk and weight, container seedlings are easy to hand or machine plant because their root

\section{Author Information}

James P Barnett

Chief Silviculturist

jbarnett/ srs_pineville@ fs.fed.us

John M McGilvray

Biological Technician

USDA Forest Service

Southern Research Station

2500 Shreveport Highway

Pineville, LA 71360 systems are uniformly shaped. The control of planting depth is critical for longleaf pine. The bud should be at about the soil surface (Figure 2).

D ibbles shaped like the root plug work well because the problem of planting too deep can be avoided. H owever, most mechanical planters designed for bareroot seedlings can be adapted for container stock with only minor modifications.

Because survival of container seedlings is very good, the planting season can be extended (Barnett and Brissette 1986). Planting longleaf seedlings in fall, as soon as adequate soil moisture is obtained, yields good field performance and reduces risk of damage from subfreezing winter temperatures. Seedlings are typically planted during June, July, and August in central and southern Florida because of ample rainfall. Root systems of fall planted seedlings become well established since they grow during winter. H eight growth is not initiated before root collar diameters reach about $2.5 \mathrm{~cm}$ (1 in), so time in the grass stage can be shortened by enhancing early development of the root system.

\section{Ref erences}

Barnett JP. 1988. Covering affects container germination of southern pine seeds. Tree Planters' N otes 29(2):13-15.

Barnett JP. 1989. Shading reduces growth of longleaf and loblolly pine seedlings in containers. Tree Planters' N otes $40(1): 23$ 26.

Barnett JP. 1997. Improving the quality of longleaf pine seeds from orchards. In: Proceedings, 24 th biennial southern forest tree improvement conference; 1997 Jun 9-12; 0 rlando, FL. G ainsville (FL): University of Florida, School of Forest Resources and Conservation. Southern Forest Tree Improvement Sponsored Publication 46. p 124-132.

Barnett JP, Brissette JC. 1986. Producing southern pine seedlings in containers. $\mathrm{N}$ ew 0 rleans (LA): USDA Forest Service, Southern Forest Experiment Station. General Technical Report SO-59. 71 p.
Barnett JP, M CG ilvray JM. 1993. Performance of container and bareroot loblolly pine seedlings on bottomlands in South Carolina. Southern Journal of Applied Forestry 17:80-83.

Barnett JP, M CG ilvray JM. 1997. Practical guidelines for producing longleaf pine seedlings in containers. A sheville (NC): USDA Forest Service, Southern Research Station. General Technical Report SRS14. $28 \mathrm{p}$.

Barnett JP, Pickens B, Karrfalt R. 1999. Improving longleaf pine seedling establishment in the nursery by reducing seedcoat microorganisms. In: Proceedings of the 10 th biennial southern silvicultural research conference; 1999 Feb 16-18; Shreveport, LA. A sheville (N C): USDA Forest Service, Southern Research Station. General Technical Report SRS-30. p 339-343.

Brissette JC, Barnett JP, Landis TL. 1991. Container seedlings. In: Duryea JL, Dougherty PM, editors. Forest Regeneration M anual. Dorcrecht, The $\mathrm{N}$ etherlands: Kluwer Academic Publishers. p 117-141.

[ITIS] Integrated Taxonomic Information System. 1998. Biological names. Version 4.0 (on-line database). URL: http:/ / www.itis.usda.gov/ plantproj/ itis/ itis_query.html (updated 15 December 1998).

Landis TL, Tinus RW, M CDonald SE, Barnett JP. 1989. Seedling nutrition and irrigation. In: The container tree nursery manual. W ashington (DC): USDA Forest Service. A gricultural Handbook 674 , Volume 4. 119 p.

Pawuk W H. 1982. Transplanting germinated seeds into containers may retard growth. Tree Planters' N otes 33(2):22-23.

South DB, Barnett JP. 1986. Herbicides and planting date affect early performance of container-grown and bare-root loblolly pine seedlings in Alabama. N ew Forests 1:17-27.

Tinus RW, Sword MA, Barnett JP. 1999. Prevention of cold damage to container grown longleaf pine roots. In: Proceedings of the 10 th biennial southern silvicultural research conference; 1999 Feb 16-18; Shreveport, LA. A sheville (N C): USDA Forest Service, Southern Research Station. General Technical Report. SRS-30. p 331-333.

W ahlenberg W G. 1946. Longleaf pine: its use, ecology, regeneration, protection, growth, and management. W a shington $(D C)$ : Charles Lathrop Pack Forestry Foundation. 429 p. 